\title{
BANYAKNYA PENYALAHGUNAAN NARKOBA DI INDONESIA
}

\section{Bagus Riswandi}

Prodi Teknik Industri Universitas Widya Mandala Surabaya di Madiun

banudwi24@gmail.com

\begin{abstract}
Abstrak
Permasalahan di Indonesia ini masih merupakan hal yang sangat dibutuhkan oleh seseorang mulai dari kalangan dewasa, remaja dan artis papan atas pun banyak menjadi pemakai, menurut Spinoza cara berada atau modus dari atribut-atribut keluasan dan pemikiran untuk menguasai hawa nafsu agar dirinya menjadi seseorang yang percaya diri. Di Indonesia ini penggunaan narkotika dan obatobatan berbahaya sudah sangat memprihatinkan, bahkan untuk masyarakat Indonesia mulai dari kalangan remaja hingga dewasa dan artis terkenal memakai bermacam-macam jenis narkoba yang illegal. Seseorang jika sudah kecanduan pemakai obat-obatan berbahaya dapat mengancam umurnya atau kematian dalam hidupnya. Faktor penyebab seseorang yang mempengaruhi untuk melakukan tindakan suatu kejahatan atau penyalahgunaan narkoba yaitu pergaulan jika seseorang sudah bergaul dengan orang yang kecanduan narkoba maka sesorang pun akan mencoba-coba narkotika dan obat-obatan berbahaya, Harus disadari bahwa penyalahgunaan narkoba adalah suatu problem yang komplek. Pencegahan dan penanggulangan narkoba dapat dilakukan dengan cara direhabilitas dengan baik agar menjadi sadar dan tidak menjadi pemakai penyalahgunaan narkoba lagi.
\end{abstract}

Kata kunci : Spinoza, kematian, sosialita, dan kejasmanian. 


\section{A. Permasalahan atau Fenomena yang diangkat}

Dalam permasalahan ini banyaknya penyalahgunaan Narkoba di Indonesia mulai dari kalangan dewasa, remaja hingga artis papan atas di Indonesia. Terbukti mulai dari kalangan Indonesia bertambahnya jumlah penyalahgunaan dan pecandu narkoba dan kejahatan kasus narkoba yang semakin meningkat, dampak penyalahgunaan narkoba ini akibatnya dapat mengancam masa depan bahkan dapat mengancam kematian dalam hidupnya.

\section{B. Teori yang digunakan}

Teori yang digunakan dalam menganalisis banyaknya penyalahgunaan narkoba di Indonesia yaitu filosof berfilsafat tentang manusia dan kematian pada bab IV dan bab $\mathrm{V}$ di buku filsafat manusia

\section{Pembahasan Masalah dan Fenomena}

Manusia menurut Spinoza adalah suatu cara berada atau modus dari atribut-atribut keluasan dan pemikiran, untuk menguasai tahap irasional, indrawi atau hawa nafsu itu. Manusia sangat sulit mengontrol hawa nafsu dalam duniawi, sehingga manusia dapat melakukan hal-hal yang buruk seperti penyalahgunaan obat-obatan berbahaya atau bisa disebut narkoba. Penggunaan narkoba di Indonesia maraknya semakin meningkat. narkoba adalah narkotika dan obat-obatan berbahaya. Tubuh manusia merupakan keseluruhan manusia dalam kejasmaniannya, kemudian mengintrodusir res cogitans yang berarti bagian dalam manusia yang berpikir, tidak bisa ditangkap indra dan mengikuti hukum roh. Dan untuk res extensa mengungkapkan badan manusia yang memiliki dimensi keluasan dan gerak, bisa diindrai dan mengikuti hukum materi. Badan dan jiwa adalah satu kesatuan substansial.badan adalah suatu jiwa yang diragakan dan untuk jiwa adalah badan yang sudah mengekspresikan sesuatu.

Di Indonesia ini penggunaan narkotika dan obat-obatan berbahaya sudah sangat memprihatinkan, bahkan untuk masyarakat Indonesia mulai dari kalangan remaja hingga dewasa dan artis terkenal memakai bermacam-macam jenis narkoba yang illegal. Hal ini dapat mempengaruhi kehidupan bangsa dan Negara pada masa yang 
mendatang. Jenis-jenis narkoba bermacam-macam yaitu ,heroin,kokain, ganja dll. heroin adalah yang dihasilkan dari morfin dengan olah secara kimiawi, dan untuk dampak penggunaan narkotika jenis heroin ini dapat berpengaruh melambatnya denyut nadi, tekanan darah menurun, otot menjadi lemas, hilang kepervcyaan diri dan suka menyendiri. Dan untuk jenis narkoba kokain adalah tanaman Erythroxylon coca yang berasal dari Amerika. Kokain digunakan dengan cara dikunyah agar dapat memicu metabolism sel menjadi sangat cepat. Dan untuk dampak penggunaan narkotika jenis kokain ini dapat berpengaruh sering merasa gelisah, dapat memberikan efek kegembiraan yang berlebihan bagi yang mengkonsumsinya/pen gguna, menurunnya berat badan, turunnya selera makan, sering merasa kebingungan dan kaburnya penglihatan. Dan untuk jenis narkoba selanjutnya adalah ganja, ganja merupakan tumbuhan budidaya yang dapat menghasilkan serat dan kandungan zat narkotika yang terdapat pada bijinya. Serat ini digunakan sebagai bahan pembuat kantung dan bijinya dapat digunakan sebagai dasar pembuatan minyak. Dan untuk dampak penggunaan jenis nakoba ganja ini dapat berpengaruh denyut nadi dan jantung semakin lebih cepat, sulit dalam mengingat, kadang-kadang sesorang jika sudah memakainya menjadi agresif, mengalami ganguan tidur, sering merasa gelisah. Jenis narkoba ganja ini dapat mengakibatkan salah satu orang jika sudah memakainya akan mengakibatkan kecanduan. Jika sesorang berhenti dalam pemakaiaan narkoba jenis ganja ini, si pemakai akan sering mengalami sakit kepala, mual yang berkepanjangan, sering merasa kelelahan dan jika sudah mengkonsumsinya badan si pamakai akan menjadi lesu. Jenis-jenis narkoba tadi sangat paling berbahaya dan banyak orang kecanduan jika sudah mengkonsusinya. Dan masih banyak lagi jenis narkoba lainnya.

Seseorang jika sudah kecanduan pemakai obatobatan berbahaya dapat menga ncam umurnya atau kematian dalam hidupnya. Manusia tidak bisa menyempurnakan diri dalam hal duniaanya. Karena dinamikanya juga terarah ke dunia. Bahwa manusia dalam perlibatan makin maju dalam dunianya, dinamika manusia itu mengarah diri ke kesempurnaan manusia. Jika seseorang sudah kecanduan dalam pengguna obat- 
obatan berbahaya maka bisa terjadi kematian. Kematian adalah suatu fakta dan tak bisa di elakkan atau berakhirnya kehidupan. Kematian yaitu pemberhentian dinamika perkembangan manusia jiwa-badan. Hingga kini penyebaran narkotika dan obatobatan berbahaya sudah tidak bisa dicegah. Karena masih banyak juga oknumoknum yang melakukan perbuatan yang tidak bertanggung jawab dengan cara menjual narkoba. Bahkan pengedar narkotika dan obat-obatan berbahaya banyak sekali modusnya, pasal dari pengedar narkotika dengan undang-undang pengedar diatur dengan pasal 114, pasal 119 dan pasal 124. Untuk pasal 114 golongan I yaitu dipidana dengan penjara seumur hidup atau pidana paling singkat 5 tahun dan untuk paling lama yaitu 20 tahun dan dengan denda 1 milyar. Dan untuk golongan II yaitu dengan pidana penjara 4 tahun dan untuk paling lama 12 tahun dengan denda paling sedikit 800 juta dan paling banyak didenda 8 milyar. Dan untuk golongan III yaitu dipidana penjara 3 tahun dan untuk paling lama 10 tahun dengan denda paling sedikit 600 juta dan dengan denda paling banyak 5 milyar. Dengan hukuman seperti ini pun pengedar tidak pernah lelah untuk melakukan kejahatannya walaupun sudah pernah masuk jeruji besi. Bahkan dalam penjara pun kemungkinan masih bisa melakukan kejahatan dengan cara menjual narkotika dan obat-obatan berbahaya, pengedar pun dapat melakukan modus dengan berbagai cara yaitu mulai disimpan di dalam sepatu, dibentuk seperti rokok dan masih banyak cara yang dapat dilakukan oleh seorang pengedar narkoba. Dan untuk Bandar narkoba sendiri meyerahkan narkotika-obatobatan berbahaya kepada pengedar narkoba. Pngedar narkoba adalah seseorang yang membeli narkotika dan obat-obatan berbahaya dari Bandar narkoba untuk dijual belikan kepada konsumen yang sudah kecanduan dalam pemakai narkoba sedangkan untuk Bandar narkoba yaitu orang yang menyuplai ke beberapa tempat untuk dibeli oleh pengedar.

Faktor penyebab seseorang yang mempengaruhi untuk melakukan tindakan suatu kejahatan atau penyalahgunaan narkoba yaitu pergaulan jika seseorang sudah bergaul dengan orang yang kecanduan narkoba maka sesorang pun akan mencoba-coba narkotika dan obat-obatan berbahaya, dan kebanyakan sesorang yang sudah 
melakukan penyalahgunaan narkoba maka seorang pemakai pun sangat sulit untuk berhenti karena jika sudah kecanduan narkotika dan obat-obatan berbahaya maka jika berhenti akan terasa mual dan pusing. Dan untuk yang kedua jika seseorang melakukan penyalahgunaan narkoba yaitu sosial atau masyarakat, masyarakat yang baik terbentuk dari organisasi yang baik dan terkontrol. Begitu juga sebaliknya jika masyarakat tidak terkontrol dengan baik maka lingkungan akan memperngaruhi kita untuk melakukan hal-hal yang tidak baik atau bisa disebut kejahatan, dengan contoh melakukan perbuatan dengan cara penyalahgunaan narkoba. Penyebab sesorang dengan terjerumusnya penyalahgunaan narkoba yaitu kepribadian, apabila sesorang mempunyai kepribadian yang labil atau kurang baik maka sesorang itu sangat mudah terpengaruhi dalam terjerumusnya penyalahgunaan narkoba. dan yang kedua bisa jadi dengan keluarga, jika seseorang dalam hubungan keluarga mengalami broken home maka seseorang itu akan mengalami frustasi dalam hubungannya sehingga seseorang itu akan melakukan penyalahgunaan narkoba agar dalam pikirannya menjadi lebih tenang dan tidak sama sekali teringat tentang masalah dalam keluarganya. Sedangkan yang ketiga bisa jadi karena ekonomi yang sulit dalam mencari pekerjaan, seseorang jika sulit dalam mencari pekerjaan maka orang itu akan melakukan kejahatan dengan cara menjadi pengedar narkoba, karena jika menjadi pengedar narkoba keuntungannya pun sangat banyak dan menjadi pengedar narkoba tidak perlu memiliki ijazah yang tinggi atau bahkan sama sekali tidak memerlukan ijazah, bahkan untuk menjadi pengedar narkoba pun sangatlah mudah, di masa sekarang apapun yang dilakukan tidak dipikirkan untuk masa depannya karena dengan keterbatasan ekonomi sesorang akan melakukan apa saja untuk mendapatkan uang, bahkan apa yang dilakukannya itu salah yang terpenting mendapatkan uang.

Secara umum sesorang yang sudah melakukan penyalahgunaan narkoba dapat terlihat dari fisik,psikis dan social seseorang. Dampak fisik,psikis dan social selalu berhubungan antara satu dengan lainnya. Selain itu dapat menimbulkan perubahan perilaku, perasaan dan kesadaran. Efek yang ditimbulkan dalam penyalahgunaan narkoba atau narkotika dan obat-obatan berbahaya yaitu menjadi depresan, depresan 
yaitu suatu sistem saraf pusat dan dapat mengurangi aktifitas fungsional tubuh agar menjadi tenang dan bahkan bisa tidur dengan nyenyak dan tak sadarkan diri. Tetapi jika seseorang yang menjadi pemakai narkoba terus menerus maka akan mengakibatkan dosis menjdai tinggi dan bisa menjadi penyebab kematian kepada seorang pemakai. Dan yang kedua adalah stimulan, yang dapat merangsang tubuh dan menjadi peningkatan dalam kegairahan serta kesadaran. Sedangkan yang ketiga halusinogen, yang dampaknya seseorang jika sudah mengkonsumsi narkoba akan menjadi halusinasi. Maka kenapa seseorang mulai dari kalangan remaja, dewasa bahkan sampai artis papan ataspun menjadi pemakai narkoba, karena jika sesorang yang sudah mengkonsumsinya atau bisa disebut kecanduan akan sulit dihilangkan karena narkotika dan obat-obatan berbahaya dapat membuat tubuh dan pikiran menjadi tenang dan santai. Harus disadari bahwa penyalahgunaan narkoba adalah suatu problem yang komplek. Pencegahan dan penanggulangan narkoba dapat dilakukan dengan cara direhabilitas dengan baik agar menjadi sadar dan tidak menjadi pemakai penyalahgunaan narkoba lagi. 


\section{DAFTAR PUSTAKA}

Dewantara, Agustinus. "Filsafat Moral (Pergumulan Etis Keseharian Hidup Manusia)." (2017) 